\title{
Pathologic evaluation of testis and epididymis of hairy rams in the semi-arid region of Piaui State
}

[Avaliação patológica de testículos e epidídimos de ovinos deslanados da região semi-árida do Estado do Piaui]

\author{
F.L.A. Costa ${ }^{1}$, S.M.M.S. Silva ${ }^{1}$, E.F. Nascimento ${ }^{2}$ \\ ${ }^{1}$ Departamento de Clínica e Cirurgia Veterinária - UFPI \\ Campus da Socopo \\ 64049-550 - Teresina, PI \\ ${ }^{2}$ Escola de Veterinária - UFMG - Belo Horizonte, MG
}

\begin{abstract}
The gross and histological examinations of testis and epididymis of 53 crossbred hairy rams in the semiarid region of Piaui State showed $34(64.1 \%)$ animals with pathologic changes: one animal presented (1.9\%) testicle hipoplasia; $35(66 \%)$ degenerative changes, being $13(24.5 \%)$ related to testicular degeneration, three $(5.7 \%)$ to intraepithelial cysts in the epididymal epithelia and $19(35.8 \%)$ to retention cysts in the epididymis; $11(20.7 \%)$ inflammatory alterations, being five $(9.4 \%)$ related to epididymitis, four $(7.5 \%)$ to orchitis and two $(3.8 \%)$ to spermatic granulomas. The animals with hypoplasic testicle, testicular degeneration and inflammatory alterations were classified as sub-fertile.
\end{abstract}

Keywords: hairy rams, testis, epididymis, pathology

\section{RESUMO}

Os exames macroscópico e microscópico de testículos e epidídimos de 53 ovinos deslanados da região semi-árida do estado do Piauí revelaram34 (64,1\%) animais acometidos por processos patológicos, assim distribuidos: um animal (1,9\%) apresentou hipoplasia testicular, 35 (66,0\%) mostraram alterações degenerativas, sendo 13 (24,5\%) casos de degeneração testicular, três (5,7\%) de cisto intraepitelial no epidídimo e 19 (35,8\%) de cisto de retenção congênita no epidídimo; 11 (20,7\%) de alterações inflamatórias, sendo cinco $(9,4 \%)$ de epididimite, quatro $(7,5 \%)$ de orquite e dois $(3,8 \%)$ de granuloma espermático. Os animais com hipoplasia testicular, degeneração testicular e alterações inflamatórias foram classificados como subférteis.

Palavras-chave: ovinos, testículo, epidídimo, patologia

\section{INTRODUCTION}

Pathologic changes in testis and epididymis of rams are few studied compared with others domestic animals, especially hairy rams living in semi-arid regions, like the Northeast of Brazil, where high temperatures, nutritional deficiency, and lack of feed are present. Besides, the animals are exposed to many pathogens, since that the sanitary conditions in these areas are usually very precarious. These are well known factors that interfere with reproductive activity in domestic animals (Palfi et al., 1989; Van Niekerk and Van Niekerk, 1989; Sokkar et al., 2003.

Due to the importance of the integrity of the genital organs on reproductive performance of the animals, some studies about genital alterations in rams were performed around the world. An unique study which was held in the Northeast of Brazil detected testicular degeneration, epididymo-orchitis, and testicular 
hypoplasia in rams that have already presented reproductive problems (Santa Rosa et al., 1990). In Australia, testis degeneration, epididymitis and spermatic granuloma were registered in rams (Watt, 1978). Similar alterations were also described in Scotland (MacLaren, 1988). Other studies investigated the probable causes of testicular hypoplasia (Galloway et al., 1992), sperm stasis and orchitis in rams (Ashdown and Ford, 1967; Krishna et al., 1977), and described the morphology of spermatic granuloma (Saravanamuthu et al., 1991). Testicular and epididymal alterations, similar to those observed in rams, were also studied in goats (Vinha et al., 1980), cattle (Ladds et al., 1973; Nascimento et al., 1981; Maia et al., 1983), and roosters (Santa Rosa et al., 1981).

The objective of this paper was to describe testicular and epididymal changes in hairy rams in the semi-arid region of Piaui State.

\section{MATERIAL AND METHODS}

A total of 53 crossbred hairy rams aging from 15 to 36-month-old of the semi-arid region of Piaui State were investigated. The animals were kept in extensive system and native pasture and exposed to medium temperature ranging from 26 to $32^{\circ} \mathrm{C}$ throughout the year (Atlas..., 1990). Reproductive problems were not reported in these animals were not related despite lack of any veterinary assistance. After evaluation of the overall aspect of the animals, inspection and palpation of the scrotum and scrotal pouch, gonads and epididymis were colleted by chirurgic castration and they were grossly examined. Fragments of $0.5 \mathrm{~cm}$ of the caput, body and cauda of the testis and epididymis were colleted. This material was fixed in Bouin's fluid from 24 to 48 hours and conserved in $70 \%$ alcohol. The samples were embedded in paraffin and trimmed from 4 to $5 \mu \mathrm{m}$ in thickness, deparaffinezed in xylene, and dehydrated in increasing concentration of alcohol. Sections were stained routinely with haematoxylin and eosin (Prophet et al., 1992). In addition to routine examination of all sections, observations were made on spermatogenesis, according to Mies Filho, 1987.

\section{RESULTS AND DISCUSSION}

Thirty-four (64.1\%) of the 53 hairy rams presented alterations in testis and/or epididymis. The histopathologic results, according to the nature, location and frequency of the lesions are show in Table 1. In some cases, several alterations in a same organ were observed, thus, the total of diagnostics $(n=47)$ was higher than the total number of animals with lesions $(n=34)$.

Table 1. Frequency of alterations in testicle and epididymis in 34 hairy rams in the semi-arid region of Piaui State, Brazil

\begin{tabular}{|c|c|c|c|c|c|c|c|c|}
\hline \multirow{3}{*}{ Alteration } & \multicolumn{6}{|c|}{ Organ } & \multirow{3}{*}{$\mathrm{n}$} & \multirow{3}{*}{$(\%)$} \\
\hline & \multicolumn{3}{|c|}{ Testis } & \multicolumn{3}{|c|}{ Epididymis } & & \\
\hline & $\mathrm{B}$ & UR & UL & B & UR & UL & & \\
\hline Development & & & & & & & 1 & 1.9 \\
\hline Focal hypoplasia & - & - & 1 & - & - & - & 1 & 1.9 \\
\hline Degenerative & & & & & & & 35 & 66.0 \\
\hline Retention cysts & - & - & - & 9 & 4 & 6 & 19 & 35.8 \\
\hline Intraephitelial cysts & - & - & - & 1 & 1 & 1 & 3 & 5.7 \\
\hline Degeneration & 6 & 2 & 5 & - & - & - & 13 & 24.5 \\
\hline Inflammatory & & & & & & & 11 & 20.7 \\
\hline Orchitis & - & 2 & 2 & - & - & - & 4 & 7.5 \\
\hline Epididymitis & - & - & - & - & 2 & 3 & 5 & 9.4 \\
\hline Spermatic granuloma & - & - & - & - & 2 & - & 2 & 3.8 \\
\hline Total & 6 & 4 & 8 & 10 & 9 & 0 & 47 & - \\
\hline$\%^{2}$ & 12.8 & 8.5 & 17 & 21.2 & 19.2 & 21.3 & 100 & - \\
\hline
\end{tabular}

$\mathrm{B}=$ bilateral, $\mathrm{UR}=$ unilateral right, $\mathrm{UL}=$ unilateral left.

${ }^{1}$ Percent determined in relation to the total number of animals.

${ }^{2}$ Percent determined in relation to the total number of diagnostics. 
The gross and histopathological examinations of these lesions were similar to those described in other species (McEnteen, 1990; Jubb et al., 1994). Therefore, results described here will be mainly related to an overall view of the histopathological aspects of the lesions diagnosed.

The animal with hypoplasia was $30 \mathrm{~kg}$ and 16month-old. The lesion was not detected grossly and the histopathological examination revealed left seminiferous tubules of small diameter with absence of germinal cells and lined only by Sertoli cells. The right tubules presented spermatogenic activity, but with variable degrees of degeneration and sperm stasis. Fibrosis and inflammatory infiltrate of mononuclear cells were also observed between tubules in the interstitium.

The retained cysts were solitaries, found on the lower region of the epididymal caput, but in some rare cases they were double and found both in the head and tail or only in the head or epididymal body. They were lined by a semitransparent membrane and were from 1 to $8 \mathrm{~mm}$ diameter. Microscopically, they were formed by one cavity lined by simple cubic epithelia with one external layer of smooth muscle.

The microscopy of intraepithelial cysts in the epithelium of the epididymal duct showed cystic structures distributed along the epithelia of the epididymal duct, body and head, lined by a thin conjunctive capsule and absence of inner epithelia (Fig. 1). In one case, the cyst reached considerable development (Fig. 2).

The animals with testicular degeneration were $27.8 \mathrm{~kg}$ and 17 -month-old. In one animal, the surface of cut of the testis revealed mineralization of the parenchyma, under the tunica albuginea near the testicular mediastinum, of moderate intensity. Microscopically, the degeneration was characterized by the presence of seminiferous tubules with few expressive spermatogenic activity, spermatogonias with vacuolization of cytoplasm and pyknotic nucleus (Fig. 3). The most severe lesions, observed in six animals, were characterized by seminiferous tubules lined only by one layer of cells (Fig. 4) with hyalinization and thickening of the basal membrane. In four rams, some tubules were fragmented and occupied by one eosinophilic granulous mass. Other tubules showed sperm stasis and increase of the interstitial conjunctive tissue. The simultaneous occurrence of testicular degeneration and focal hypoplasia in one animal and degeneration and orchitis in four animals were observed.

The animals with orchitis were $30 \mathrm{~kg}$ and 17.2month-old. The lesions were unilateral and degenerative alterations were also present. Microscopically, two types of inflammatory reaction were seen. The first was characterized by the presence of lymphocytes, plasma cells, and fibrosis between seminiferous tubules. In the second type, besides the infiltration of inflammatory cells, there was coagulation necrosis in the seminiferous tubules (Fig. 5).

Unilateral epididymitis was observed in five rams as following: in the caput (one ram), body (one ram) and cauda (three rams) of the epididymis. The mean weight of the animals was $26.2 \mathrm{~kg}$ and mean age was 16.8 months. Microscopically, the lesions were focal and characterized by the presence of lymphocytes and proliferation of interstitial connective tissue.

Two cases of spermatic granulomas were found, one in the head and the other in the cauda of the left epididymis. The average weight of these animals was $29.5 \mathrm{~kg}$ and the average age was 16.5 months. The increase of volume in the affected region was observed to the palpation in both cases. The lesion presented soft consistence and to the cut revealed cavitations with a white yellow exudate. To the light microscope, rupture of the basal membrane of epidimal ductules and sperm extravasations to the interstitial tissue were observed. The inflammatory infiltrate was characterized by the presence of lymphocytes, plasma cells, eosinophils and conjunctive tissue in proliferation (Fig. 6).

From the 34 animals with testicular and epididymal changes, $20(37.7 \%)$ had lesions that probably could compromise the fertility according to McEntee (1990), being one ram with testicular hypoplasia, 13 with testicular degeneration, four with chronic orchitis, two with spermatic granulomas, and five with chronic focal epididimytis. This frequency was higher than the $14.8 \%$ registered by MacLaren (1988). Watt (1978) founded a low percent of animals $(20 \%)$ with lesions that compromised the 
fertility. The remaining $14(26.4 \%)$ animals presented lesions that probably would not compromise the reproductive function. In this group of animals, the diagnostics were congenital retention cysts and intraepithelial cysts in the epididymis.

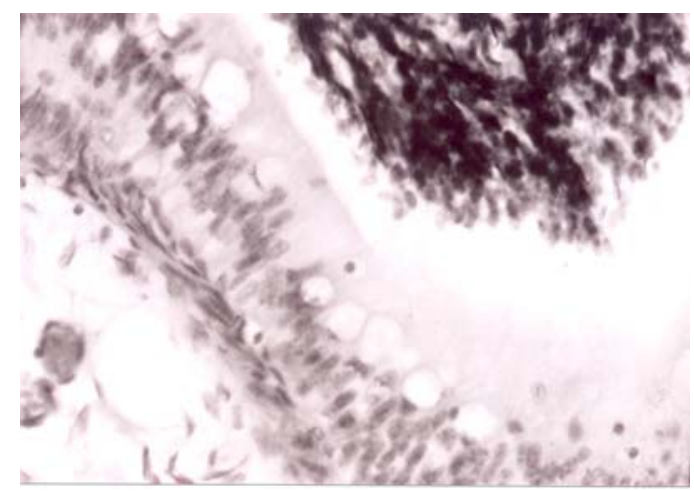

Figure 1. Epididymis of hairy rams. Cystic structures distributed along the epithelia of the epididymal duct. HE, 140x.

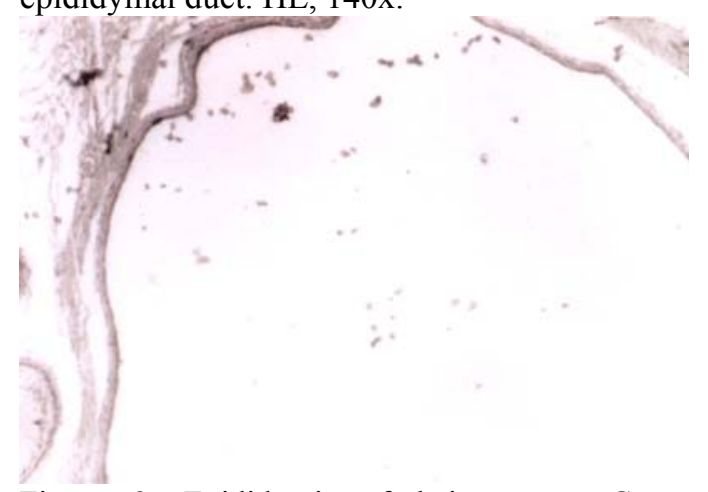

Figure 2. Epididymis of hairy rams. Cyst structure reached considerable development. HE, 140x.

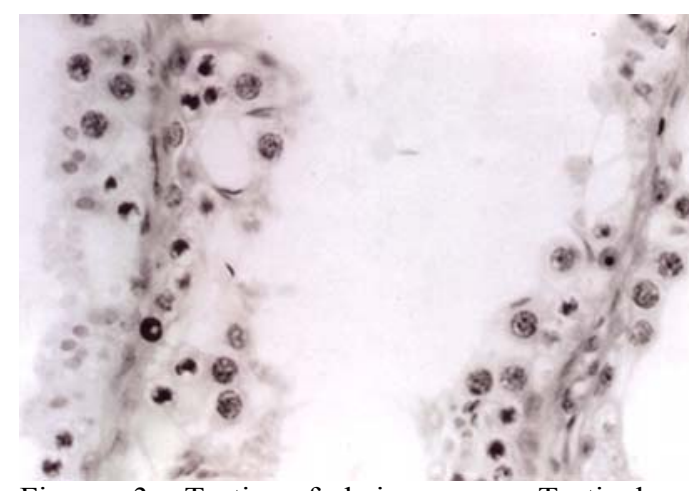

Figure 3. Testis of hairy rams. Testicular degeneration. Seminiferous tubules with few expressive spermatogenic activity and spermatogonias with cytoplasm vacuolization and pyknotic nucleus. HE, 140x.

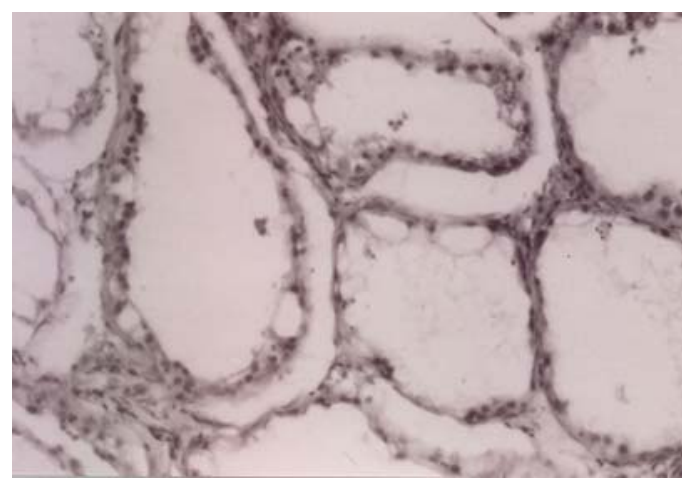

Figure 4. Testis of hairy rams. Testicular degeneration. Seminiferous tubules lined only by one layer of cells and cytoplasm vacuolization. HE, 140x.

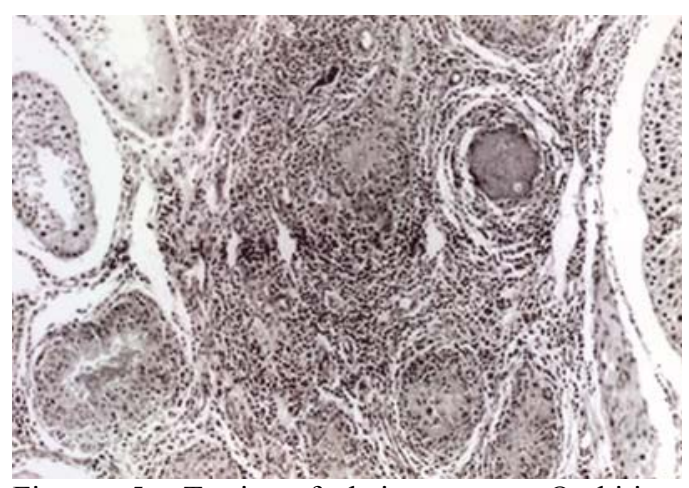

Figura 5. Testis of hairy rams. Orchitis. Inflammatory infiltrate characterized by the presence of lymphocytes and plasma cells and coagulation necrosis in seminiferous tubules. HE, 140x.

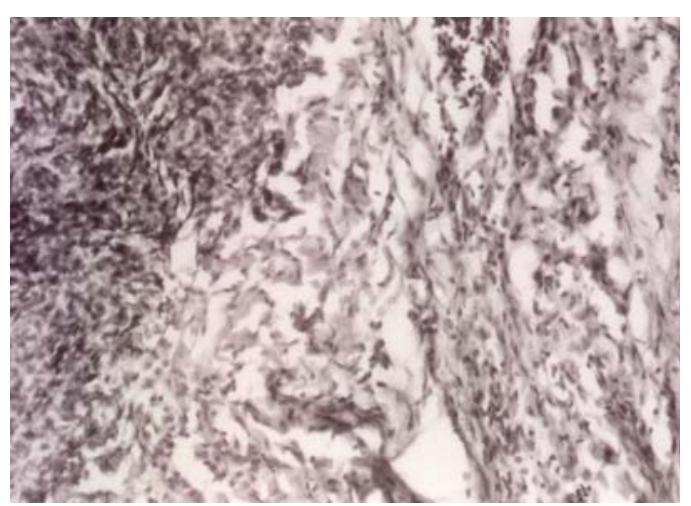

Figure 6. Epididymis of hairy rams. Spermatic granuloma. Rupture of the basal membrane of epidimal ductules and sperm extravasations to the interstitial tissue. HE, 70x. 
The analysis of the semen revealed that $8.3 \%$ presented spermatic alterations. This percent does not correspond to the number of animals with testicular and epididymal changes (37.7\%) which may compromise the fertility. However, most of the lesions were of focal distribution and unilateral and, therefore, did not compromise a large extension of the organ. These findings suggest that high spermatic alterations in hairy rams occur in the cases with histopathologic changes in more extensive testicular and epididymal tissue. Besides, some studies have shown that hairy rams are well adapted to the adverse conditions of high temperature in Brazil (Simplício et al., 1982.; Freitas et al., 1989). Most of the injures were observed in animals aging from 15 to 20 -month-old and weighting from 26.2 to $30 \mathrm{~kg}$.

Studies concerning testicular and epididymal pathology in hairy rams of the semi-arid region in the Northeast of Brazil are very scarce or even inexistent. Thus, these results can be important to subsidize further studies about reproductive problems in the animals of this region.

Studies on testicular hypoplasia in rams seem to be rare and its cause is not well known. However, toxins of the fungus Helminthosporium biseptatum and water with high concentrations of arsenic were considered as the causes of testicular hypoplasia in $37 \%$ of rams born from mothers fed this water in early pregnancy (Galloway et al., 1992). A higher incidence of testicular hypoplasia $(4.7 \%)$ was also found by MacLaren (1988). The incidence of hypoplastic testicle observed in this study is similar to that one registered in others species (Ladds et al., 1973).

Congenital retention cysts can be present in all domestic species and they are located between the epididymal head and the testis. These cysts are vestige of the Wolff ducts and do not provoke infertility (McEntee, 1990). Lower frequency of this alteration was found in goats (20\%) (Vinha et al., 1977) and cattle (1.3\%) (Nascimento et al., 1981).

Intraepithelial cysts may not interfere on fertility. These cysts are observed in other species and can occur or not in the presence of inflammation (Mosaheb et al., 1973). Lower percentage of them were found in goats $(3.0 \%)$ (Vinha et al.,
$1980)$ and higher in cattle (8.0\%) (Nascimento et al., 1981).

Abnormal sperm, as detected in the animals of this study, can be a consequence of testicular degeneration in cases of mineral deficiencies, high environmental temperature and inflammatory alterations (Van Niekerk and Van Niekerk, 1989; McEntee, 1990; Rege et al., 2000; Sokkar et al., 2003). The animals of this study were submitted to these adverse conditions. It seems that age have not influenced on the occurrence of the degenerative process, since all animals were relatively young (aging from 15 to 20 -month-old).

Seasonal changes in semen quality and serum testosterone were described in rams of tropical region (Gundogan and Elitok, 2004). These can be due to the degeneration caused by the effect of high temperatures on gonads as it was observed in bulls (Kumi-Diaka et al., 1981). The $24.5 \%$ of testicular degenerations found in this study was higher than the $13 \%$ found by Watt (1978) and lower than the $37.5 \%$ registered by Santa Rosa et al. (1990) in Santa Inês, Somalis and Morada Nova rams. However, these animals had already presented reproductive problems. In goats, the percent is close to the observed in this study (16.2\%) (Vinha et al., 1980), but in cattle $(42.7 \%)$ (Nascimento et al., 1981) and in rooster (42.1\%) (Santa Rosa et al., 1981) the percents were higher. The absence of gross alterations in the intact testis as observed in this study was described by McEntee (1990) in cases of degeneration of medium or moderate intensity.

Orchitis in rams can be of infectious or immune origin (Saravanamuthu et al., 1991). This injury can be associated to the degeneration and it seems to be a frequent event due to heat caused by inflammation of the infected testis, as observed in dogs (McEntee, 1990). Similar reaction was observed in rams infected by maedi/visna virus (Palfi et al., 1989), and 8.7\% and $8.3 \%$ were found by MacLaren (1988) and Santa Rosa et al. (1990), respectively. Lower value was observed by Vinha et al. (1980) in goats $(4.6 \%)$.

Epididymitis is more frequently located in the epididymal cauda, probably because it is in the cauda of the epididymis where intraepithelial lymphocytes are more numerous due to 
spermatozoa degeneration (McEntee, 1990). On the other hand, Corynebacterium ovis is a frequent cause of caseous lymphadenitis in rams in the Northeast of Brazil, and can be involved in cases of epididymitis. This fact was observed in India, by Krishna et al. (1977), in rams with epididymo-orchitis. The frequency of epididymitis $(9.4 \%)$ was higher than the frequency of $0.8 \%$ observed by Watt (1978), and lower than that registered by Santa Rosa et al. (1990), being $25 \%$. In that study, rams were deferectomized, which seems to favour the occurrence of the lesion. These lesions were similar to the epididymitis described by McEntee (1990), frequently present in the interstitio of the deferent ducts in domestic animals.

Palpable lesions of the scrotum of rams are located in the epididymis and can result of spermatic granulomas (Watt, 1978). For Jubb et al. (1994), this lesion is frequently located in the epididymal caput. The granulomatous response develops when an acid-fast material contained in the sperm escape into the adjacent connective tissue (McEntee, 1990). The origin of the lesion is not clear but it can be of congenital or acquired nature. Ashdown and Ford (1967) related the occurrence of a case of bilateral sperm stasis in ram, probably of congenital origin. In this study, the lesion was probably of acquired origin, since it was not associated to any type of apparent congenital alteration. The frequency of this lesion in rams described by Watt (1978) was $2 \%$. Lower percent $(0.4 \%)$ was registered by Ladds et al. (1973), in bulls.

The high frequency of lesions in reproductive organs of hairy rams living in semi-arid regions indicates that the adoption of more adequate practices of management, nutrition and sanitary must be implemented.

\section{REFERENCES}

ATLAS - Estado do Piauí. Rio de Janeiro: IBGE/Fundação CEPRO, 1990. 26p.

ASHDOWN, R.R.; FORD, C.M. Bilateral epididymal spermiostasis in a ram. Vet. Rec. v.80, p.492-494, 1967.

FREITAS, V.J.F.; RODRIGUES, M.R.; SILVA, J.N. Produção espermática de ovinos das raças
Santa Inês e Morada Nova. Rev. Bras. Reprod. Anim., v.13, p.208, supl.1, 1989

GALLOWAY D.B.; WRIGHT P.J.; DE KRETSER, D. et al. An outbreak of gonadal hypoplasia in a sheep flock: clinical, pathological and endocrinological features, and aetiological studies. Vet. Rec., v.131, p.506-1, 1992.

GUNDOGAN, M.; ELITOK, B. Seasonal changes in reproductive parameters and seminal plasma constituents of rams in Afyon province of Turkey. Dtsch. Tierarztl Wochenschr., v.111, p.158-161, 2004.

JUBB, K.V.F.; KENNEDY, P.C.; PALMER, N. (Eds). Pathology of domestic animals. 4.ed. San Diego: Academic, 1994. 651p.

KRISHNA, L.; KULSHRESTHA, S.B.; PALIWAL, OP. Epididymo-orchitis im ram due to C. ovis. Indian Vet. J., v.54, p.517-519, 1977.

KUMI-DIAKA， J.; NAGARATNAM， V.; RWUAAN, J.S. Seasonal and age-related changes in semen quality and testicular morphology of bulls in a tropical environment. Vet. Rec., v.108, p.13-15, 1981.

LADDS, P. W.; DENNETT, D. P.; GLAZEBROOK, J. S. A survey of the genitalia of bulls in Northern Australia. Aust. Vet. J., v.49, p.335-340, 1973.

MacLAREN, A.P.C. Ram fertility in South-west Scotland. Br. Vet. J., v.144, p.45-54, 1988.

MAIA, P.C.C.; NASCIMENTO, E.F.; CHIQUILOFF, M.A.G. Alterações testiculares e epididimárias em bovinos: orquite e epididimite. Arq. Bras. Med. Vet. Zootec., v.35, p.373-379, 1983.

McENTEEN, K. Reproductive pathology of domestic mammals. San Diego: :Academic, 1990, 410p.

MIES FILHO, A. Inseminação artificial. 6.ed. Porto Alegre: Sulina, 1987. v.2, 736p.

MOSAHEB, M.F.; LADDS, A.H.; LADD, P.W. The pathology of the external genitalia of bulls in Northern Australia. Aust. Vet. J., v.49, p.512516, 1973. 
NASCIMENTO, E. F.; MAIA, P. C.C.; CHIQUILOFF, M. A G. et al. Alterações testiculares e epididimárias em bovinos: II Degeneração e cistos intraepiteliais no epidídimo. Arq. Esc. Vet. UFMG, v.33, p.407412, 1981.

PALFI, V.; GLAVITS, R.; HAJTOS, I. Testicular lesions in rams infected by maedi/visna virus. Acta. Vet. Hung., v.37, p.97$102,1989$.

PROPHET, E.B.; MILLS, B.; ARRINGTON, J.B. et al. (Eds). Laboratory methods in histotechnology. Washington: Armed Forces Institute of Pathology, 1992. 275p.

REGE. J.E.; TOE1, F.; MUKASA-MUGERWA, E. et al. Reproductive characteristics of Ethiopian highland sheep. II. Genetic parameters of semen characteristics and their relationships with testicular measurements in ram lambs. Small Rumin. Res., v.37, p.173-187, 2000.

SANTA ROSA, J.; SILVA, J.M.L.; NASCIMENTO, E.F. et al. Alterações testiculares e epididimárias em Gallus gallus domesticus. II. Degeneração testicular. Arq. Esc. Vet. UFMG, v.33, p.419-423, 1981.

SANTA ROSA, J.; SIMPLÍCIO, A.A.; MACHADO, R. Alteração do sistema genital de ovinos deslanados. Rev. Bras. Reprod. Anim., v.14, p.175-185, 1990.

SARAVANAMUTHU, R.A.; FOSTER, P.W.; LADDS, M.D. T and B lymphocytes subsets in spermatic granuloma in five rams. Vet. Pathol., v.28, p.482-491, 1991.

SIMPLÍCIO, A.A.; RIERA, G.S.; NELSON, E.A. et al. et al. Seasonal variation and seminal and testicular characteristics of Brazilian Somali rams in the hot semi-arid climate of tropical Northeast Brazil. J. Reprod. Fertil., v.66, p.735$738,1982$.

SOKKAR, S.M.; DARWIESH, G.; MADBOOLY. A. Study of the pathological effect of Escherichia coli endotoxin in rams. $J$. Vet. Med. B. Infect. Dis. Vet. Public Health, v.50, p.226-230, 2003.

VAN NIEKERK, F.E.; VAN NIEKERK, C.H. The influence of experimentally induced copper deficiency on the fertility of rams. I. Semen parameters and peripheral plasma androgen concentration. J. S. Afr. Vet. Assoc., v.60, p.2831, 1989.

VINHA, N.A.; HUMENHUK, R.A.; NASCIMENTO, E.F. Observações preliminares sobre a patologia do testículo e epidídimo de caprinos. IV. Formações vesiculares no epitélio do ducto epididimário. Arq. Esc. Vet. UFMG, v.29, p.239-234, 1977.

VINHA, N.A.; SANTOS, M.R.C.; HUMENHUK, R.A Observações preliminares sobre a patologia do testículo e epidídimo em caprinos. V. Alterações testiculares. Arq. Esc. Vet. UFMG, v.32, p.7-13, 1980.

WATT, D.A. Testicular pathology of merino rams. Aust. Vet. J., v.54, p.473-478, 1978. 